Check for updates

Cite this: RSC Adv., 2018, 8, 42262

\title{
The influence of phosphine ligand substituted [2Fe2S] model complexes as electro-catalyst on proton reduction $\uparrow$
}

\author{
Xia Zhang,.$^{\text {abc }}$ Xiaoyuan Ma, $\ddagger^{\text {a }}$ Tianyong Zhang, ${ }^{\text {*acd }}$ Bin Li, (D) *acd Shuang Jiang, ${ }^{\text {*acd }}$ \\ Guanghui Zhang, ${ }^{a}$ Li Hai, $^{a}$ Jingchao Wang ${ }^{a}$ and Xiao Shao ${ }^{a}$
}

\begin{abstract}
To probe the influence of phosphine ligand substitution on the well-known [2Fe2S] model, two new [FeFe]hydrogenase model complexes with the phosphine ligands, $\mathrm{PMe}_{3}$ or $\mathrm{P}\left(\mathrm{CH}_{3} \mathrm{O}\right)_{3}$, were synthesized, such as

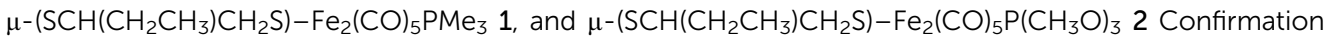
of structures was provided by FTIR, ${ }^{1} \mathrm{H}$ NMR, ${ }^{13} \mathrm{C} N M R,{ }^{31} \mathrm{P} \mathrm{NMR}$, elemental analyses and single-crystal $\mathrm{X}$ ray analysis. The crystal structure of complex 2 shows that the $\mathrm{P}\left(\mathrm{CH}_{3} \mathrm{O}\right)_{3}$ ligand has less steric effect on the coordination geometry of the Fe atom than the $\mathrm{PMe}_{3}$ ligand. In the presence of $\mathrm{HOAC}$ in $\mathrm{CH}_{3} \mathrm{CN}$ solution, the hydrogen evolution overpotentials of complexes 1 and 2 were $0.91 \mathrm{~V}$ and $0.81 \mathrm{~V}$, respectively. Comparatively, complex 2 produces hydrogen at an overpotential of $0.1 \mathrm{~V}$, lower than that for complex 1. A further electrocatalytic study showed the maximum charges for 1 and 2 were $31.3 \mathrm{mC}$ and $56.3 \mathrm{mC}$ at $-2.30 \mathrm{~V}$ for $10 \mathrm{~min}$, respectively. These studies showed that the complexes 1 and 2 have the ability, as novel electrocatalysts, for catalysis of hydrogen production, and complex 2 has better electrocatalytic ability than complex 1.
\end{abstract}

Received 27th September 2018 Accepted 24th November 2018

DOI: $10.1039 / \mathrm{c} 8 \mathrm{ra0} 08016 \mathrm{j}$

rsc.li/rsc-advances coordinated by a bridging dithiolate, terminal carbonyls and cyanide ligands. ${ }^{8}$ From then onwards, scientists began to simulate the structure and function of the active centers of $[\mathrm{FeFe}$-hydrogenases. Many research groups have designed and synthesized a number of $[2 \mathrm{Fe} 2 \mathrm{~S}]$ model complexes based on the structure of natural [FeFe]-hydrogenases by changing the types of bridging dithiolates or by introducing different ligands, such as P-donor ligands, ${ }^{9} \mathrm{~N}$-donor ligands ${ }^{10} \mathrm{~S}$-donor ligands ${ }^{11}$ and $\mathrm{N}$ heterocyclic carbene. ${ }^{12}$ Among them, the phosphorus ligands are easy to obtain at favorable prices. Due to the lone pair electrons on the phosphorus atom, the phosphorus ligands have strong coordination ability, which can transform into very stable complexes with transition metals. Additionally, their electronic effects are much like cyanides, hence it is advantageous to synthesize model compounds that are closer to natural hydrogenases. ${ }^{13-16}$ Based on the excellent properties of phosphorus ligands, many researchers have introduced a variety of different phosphorus compounds, including monodentate phosphorus ligands, bidentate phosphorus ligands and nitrogen-doped phosphorus compounds, for example, triphenylphosphine, tricyclohexylphosphine, ${ }^{17} \mathrm{Ph}_{2} \mathrm{P}-\mathrm{R}-\mathrm{PPh}_{2}[\mathrm{R}=$ $-\mathrm{CH}_{2} \mathrm{CH}_{2}-$ (dppe), $\mathrm{Z}-\mathrm{CH}=\mathrm{CH}-(\mathrm{dppv}), 1,2-\mathrm{C}_{6} \mathrm{H}_{4}(\mathrm{dppb}),-\mathrm{CH}_{2}-$ $\mathrm{CH}_{2} \mathrm{CH}_{2}$ (dpp), ferrocenyl (dppf), naphthalenyl (dppbn)], ${ }^{18}$ and PNP ligands $\left(\mathrm{PNP}=\left(\mathrm{Ph}_{2} \mathrm{P}\right)_{2} \mathrm{NR} ; \mathrm{R}=\left(\mathrm{CH}_{2}\right)_{3} \mathrm{Me},\left(\mathrm{CH}_{2}\right)_{3} \mathrm{NMe}_{2}\right.$, $\left(\mathrm{CH}_{2}\right)_{3} \mathrm{Si}(\mathrm{OEt})_{3}, \mathrm{C}_{6} \mathrm{H}_{5}, \mathrm{C}_{6} \mathrm{H}_{4} \mathrm{OMe}-p$, and $\left.\mathrm{C}_{6} \mathrm{H}_{4} \mathrm{CO}_{2} \mathrm{Me}-p\right) \cdot{ }^{19}$ Studies of such model complexes have drawn much attention since then. It is interesting to study the influence of different phosphine ligands on the active site of [FeFe]-hydrogenase model 
complexes. It is also important to find a new [2Fe2S] model complex, which can stimulate hydrogen production in the same way as natural metalloenzymes.

With this aim, we selected our previously reported synthetic complex $\mu-\left(\mathrm{SCH}\left(\mathrm{CH}_{2} \mathrm{CH}_{3}\right) \mathrm{CH}_{2} \mathrm{~S}\right)-\mathrm{Fe}_{2}(\mathrm{CO})_{6}$ as the parent complex. ${ }^{20}$ To explore the effects of phosphine ligand changes on the [FeFe]-hydrogenase model complexes, particularly the electronic and catalytic properties, our group designed two new [FeFe]-hydrogenase model complexes with the phosphine ligands $\mathrm{PMe}_{3}$ or $\mathrm{P}\left(\mathrm{CH}_{3} \mathrm{O}\right)_{3}$, namely $\mu-\left(\mathrm{SCH}\left(\mathrm{CH}_{2} \mathrm{CH}_{3}\right) \mathrm{CH}_{2} \mathrm{~S}\right)-$ $\mathrm{Fe}_{2}(\mathrm{CO})_{5} \mathrm{PMe}_{3} 1$ and $\mu-\left(\mathrm{SCH}\left(\mathrm{CH}_{2} \mathrm{CH}_{3}\right) \mathrm{CH}_{2} \mathrm{~S}\right)-\mathrm{Fe}_{2}(\mathrm{CO})_{5} \mathrm{P}\left(\mathrm{CH}_{3} \mathrm{O}\right)_{3}$ 2 , respectively. These complexes will help us better understand the practical applications of [2Fe2S] model complexes for the electrochemical generation of molecular hydrogen, as well as the correlations between the complex structure and its hydrogen production capacity.

\section{Results and discussion}

\section{Synthesis and characterization of the complexes 1 and 2}

$\mu$ - $\left(\mathrm{SCH}\left(\mathrm{CH}_{2} \mathrm{CH}_{3}\right) \mathrm{CH}_{2} \mathrm{~S}\right)-\mathrm{Fe}_{2}(\mathrm{CO})_{6}$ was prepared according to a previous synthetic method. ${ }^{20}$ Complex 1 was prepared from the reaction of $\mu-\left(\mathrm{SCH}\left(\mathrm{CH}_{2} \mathrm{CH}_{3}\right) \mathrm{CH}_{2} \mathrm{~S}\right)-\mathrm{Fe}_{2}(\mathrm{CO})_{6}$ and $\mathrm{PMe}_{3}$ in $n$ hexane at room temperature under $\mathrm{N}_{2}$ (Scheme 1). Complex 2 was obtained from the reaction of $\mu-\left(\mathrm{SCH}\left(\mathrm{CH}_{2} \mathrm{CH}_{3}\right) \mathrm{CH}_{2} \mathrm{~S}\right)-$ $\mathrm{Fe}_{2}(\mathrm{CO})_{6}$ and $\mathrm{P}\left(\mathrm{CH}_{3} \mathrm{O}\right)_{3}$ in THF in the presence of $\mathrm{Me}_{3} \mathrm{NO}$ at room temperature under $\mathrm{N}_{2}$ (Scheme 1). The complexes were purified by column chromatography on a silica gel column and recrystallized from hexane solutions.

The ${ }^{1} \mathrm{H}$ NMR spectra of complexes 1 and 2 consist of expected signals for the 1,2-butanedithiol bridges and the diverse ligands in the region 0.9-2.7 ppm, shifted slightly upfield compared to the parent complex $\mu-\left(\mathrm{SCH}\left(\mathrm{CH}_{2} \mathrm{CH}_{3}\right) \mathrm{CH}_{2} \mathrm{~S}\right)-$ $\mathrm{Fe}_{2}(\mathrm{CO})_{6}{ }^{20}$ In the ${ }^{13} \mathrm{C}$ NMR spectra, complexes 1 and 2 show peaks at $\delta=211.63,210.34$ and 209.83, 207.53 ppm, respectively. These peaks can be safely assigned to the $\mathrm{Fe}(\mathrm{CO})_{3}$ group or the $\mathrm{Fe}(\mathrm{CO})_{2} \mathrm{P}$ group. The ${ }^{31} \mathrm{P}$ NMR spectra of $\mathbf{1}$ and 2 displayed a singlet at $\delta=22.82$ and $49.75 \mathrm{ppm}$, respectively.
As shown in Fig. 1, IR spectrum of complex 1 in $n$-hexane solution consists of four characteristic bands at 2036, 1979, 1959, and $1922 \mathrm{~cm}^{-1}$. The CO stretching in complex 1 display a red shift $\left(v_{\mathrm{CO}}=10 \mathrm{~cm}^{-1}\right)$ in comparison to those in complex 2 , indicating that the $\mathrm{PMe}_{3}$ group has a stronger electron-donating ability than the $\mathrm{P}\left(\mathrm{CH}_{3} \mathrm{O}\right)_{3}$ group. Electronic influence of the phosphine ligands on the Fe-Fe core is revealed by the IR spectral data. The IR spectra of the complexes indicate that the electron density around the di-iron core decreases in the order $\mathbf{1}>\mathbf{2}$.

The crystal structures of $\mathbf{1}$ and $\mathbf{2}$ are shown in Fig. 2; the crystallographic data are shown in Table 1 and the selected bond lengths as well as bond angles are shown in Tables 2 and 3 , respectively. The Fe-Fe bond length in complex 1 (2.5235(2) $\AA)$ is longer than that in the hexacarbonyl precursor $\mu$ $\left(\mathrm{SCH}\left(\mathrm{CH}_{2} \mathrm{CH}_{3}\right) \mathrm{CH}_{2} \mathrm{~S}\right)-\mathrm{Fe}_{2}(\mathrm{CO})_{6}(2.5091(8) \AA) .{ }^{20}$ Meanwhile, the Fe-Fe bond length in complex 2 (2.4911(13) $\AA$ ) is shorter than that in the precursor $\mu$ - $\left(\mathrm{SCH}\left(\mathrm{CH}_{2} \mathrm{CH}_{3}\right) \mathrm{CH}_{2} \mathrm{~S}\right)-\mathrm{Fe}_{2}(\mathrm{CO})_{6}{ }^{20}$ In addition, the Fe-P bond length in complex 2 (2.164(2) $\AA$ ) is smaller than that of complex 1 (2.2258(3) $\mathrm{A})$, showing that the $\mathrm{P}\left(\mathrm{CH}_{3} \mathrm{O}\right)_{3}$ ligand offers a smaller steric effect on the coordination geometry of the $\mathrm{Fe}$ atom than the $\mathrm{PMe}_{3}$ group. ${ }^{15,16}$

\section{Cyclic voltammetry study}

Electrochemical properties of complexes $\mathbf{1}$ and $\mathbf{2}$ were researched to assess their redox performances and potentials as electrocatalysts for hydrogen production. To investigate the electrochemical properties of complexes 1 and 2, electroanalytical experiments were done under $\mathrm{N}_{2}$ atmosphere. The cyclic voltammograms of complexes $\mathbf{1}$ and $\mathbf{2}$ are presented in Fig. 3. Complex 1 undergoes a quasi-reversible and an irreversible reduction event at $c a$. $-2.02 \mathrm{~V}$ and $-2.37 \mathrm{~V}$, respectively. CV of complex 2 displays two irreversible reduction events at ca. $-1.98 \mathrm{~V}$ and $-2.28 \mathrm{~V}$. The first reduction is a one-electron process (one metal-centered reduction), which can be assigned to the $\mathrm{Fe}^{\mathrm{I}} \mathrm{Fe}^{\mathrm{I}} / \mathrm{Fe}^{\mathrm{I}} \mathrm{Fe}^{0}$ reduction. ${ }^{21}$ However, the family of phosphine ligands-substituted [FeFe]-hydrogenase model complexes are not usually observed to form an $\mathrm{Fe}^{0} \mathrm{Fe}^{0}$ state, so
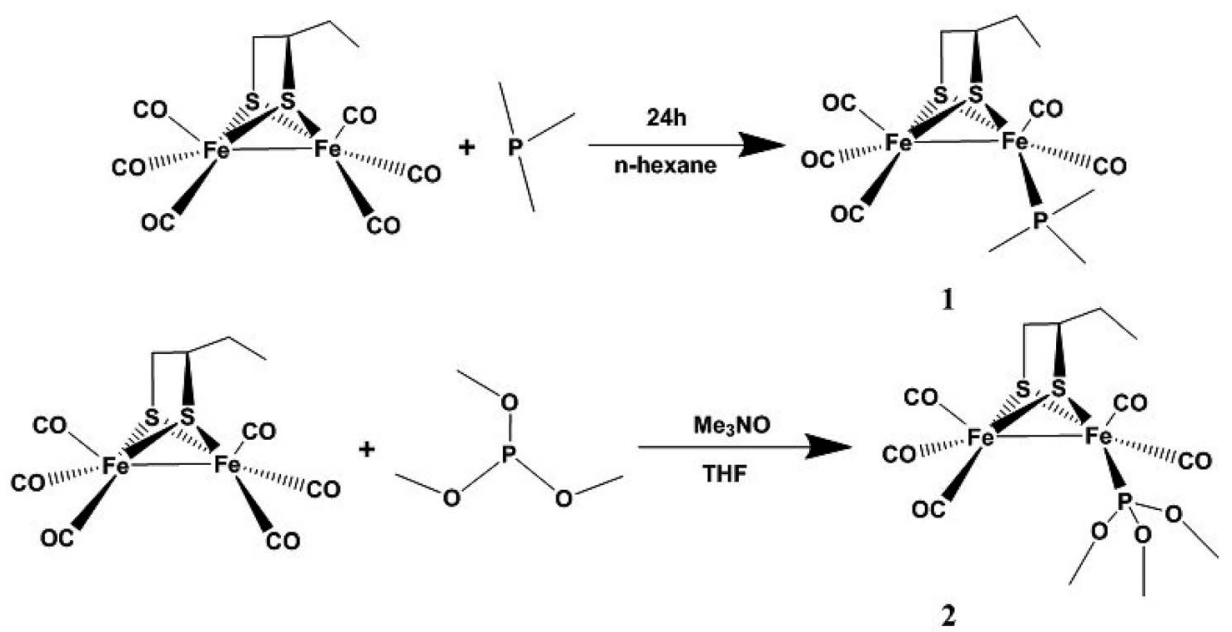

Scheme 1 The synthetic routes of compounds 1 and 2 . 


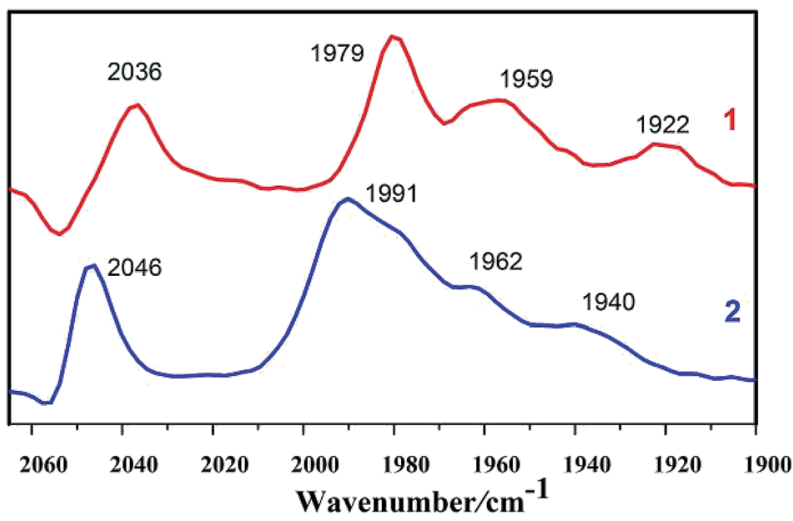

Fig. 1 IR spectra of complexes 1 and 2 in $n$-hexane solutions (CO region).

we suppose that the second reduction occurs at a ligand-center forming an $\mathrm{Fe}^{\mathrm{I}} \mathrm{Fe}^{0}$ active species. ${ }^{22}$ The first reduction peak for complex 1 shows a cathodic shift of approximately $60 \mathrm{mV}$ for the $\mathrm{Fe}^{\mathrm{I}} \mathrm{Fe}^{\mathrm{I}} / \mathrm{Fe}^{\mathrm{I}} \mathrm{Fe}^{0}$ reduction, as compared to that of the complex 2 , and this is consistent with the fact that the $\mathrm{PMe}_{3}$ ligand has

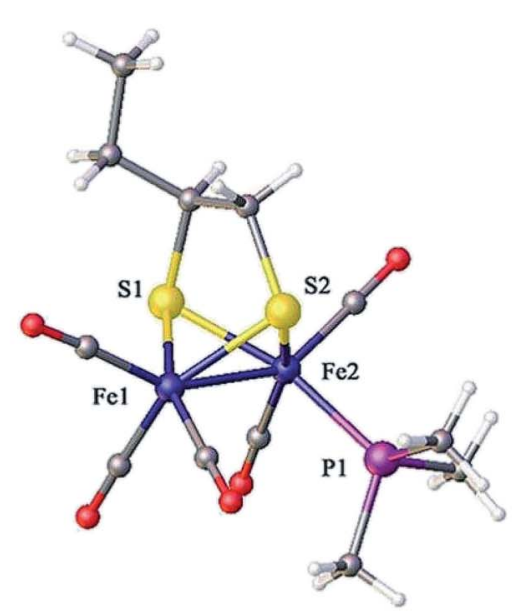

Complex 1

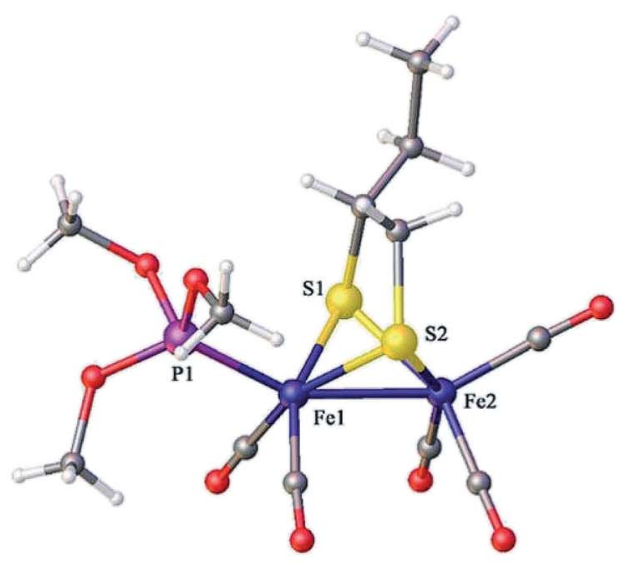

Complex 2

Fig. 2 Molecular structures of 1 (top) and 2 (bottom) with thermal ellipsoids drawn at $50 \%$ probability level. Hydrogen atoms have been omitted for clarity. a stronger electron-donating ability than the $\mathrm{P}\left(\mathrm{CH}_{3} \mathrm{O}\right)_{3}$ ligand. To determine whether the electrochemical reactions of complexes $\mathbf{1}$ and $\mathbf{2}$ are solvent-dependent or gas-dependent, as in the case of analogue complexes,,$^{15,16,20}$ the cyclic voltammetry curves were conducted under $\mathrm{CO}$ atmosphere or in $\mathrm{CH}_{2} \mathrm{Cl}_{2}$ solution. Indeed, when $\mathrm{CO}$ was present or the solvent was changed to $\mathrm{CH}_{2} \mathrm{Cl}_{2}$, the reduction peaks of complexes $\mathbf{1}$ and 2 showed a switch to a two-electron process. Voltammograms of complexes 1 and 2 under $\mathrm{CO}$ atmosphere are shown in Fig. 4. Complexes 1 and 2 showed reduction at $-2.02 \mathrm{~V}$ and $-1.98 \mathrm{~V}$, respectively, as shown in Fig. 4. These are ascribed to the process for $\mathrm{Fe}^{\mathrm{I}} \mathrm{Fe}^{\mathrm{I}} \rightarrow \mathrm{Fe}^{0} \mathrm{Fe}^{0}$ reduction. ${ }^{21}$ In view of these results for the $\mathrm{CO}$ control experiments, the second reduction peak detected under $\mathrm{N}_{2}$ is most likely due to the reduction of a new complex, which can be attributed to a coordinated solvent substituted species. As shown in Fig. 5 , in $\mathrm{CH}_{2} \mathrm{Cl}_{2}$ solution, the cyclic voltammogram data of complexes 1 and 2 reveal only a reduction peak and an oxidation peak versus $\mathrm{Ag} / \mathrm{AgNO}_{3}$, which are ascribed to the process of $\mathrm{Fe}^{\mathrm{I}} \mathrm{Fe}^{\mathrm{I}} \rightarrow \mathrm{Fe}^{0} \mathrm{Fe}^{0}$ reduction and the process of $\mathrm{Fe}^{\mathrm{I}} \mathrm{Fe}^{\mathrm{I}}$ to $\mathrm{Fe}^{\mathrm{II}} \mathrm{Fe}^{\mathrm{I}}$ oxidation, respectively, consistent with the relatively higher electron donating abilities of the ligands. These processes are attributed to the $\mathrm{Fe}^{\mathrm{I}} \mathrm{Fe}^{\mathrm{I}} / \mathrm{Fe}^{0} \mathrm{Fe}^{0}$ redox couple of a coordinated solvent substituted species, which is likely to result from a radical chain reaction initiated by the production of a radical anion.

\section{Catalytic reduction property}

To investigate the possible electrocatalytic activities of complexes 1 and 2, the electrocatalytic property towards $\mathrm{H}_{2}$ production of complexes $\mathbf{1}$ and $\mathbf{2}$ was investigated in the presence of $\mathrm{HOAc}$ in $\mathrm{CH}_{3} \mathrm{CN}$ (Fig. 6). In the study of $\mathrm{CV}$ of complex $\mathbf{1}$, HOAc (0-8 mmol) was added continuously and a new reduction potential appeared at $-2.37 \mathrm{~V} v s$. $\mathrm{Ag} / \mathrm{AgNO}_{3}$, which continuously moved to a more negative potential. The first reduction potential in the CV of complex 1 slightly increased with the addition of HOAc. In contrast, the new peak intensity significantly increased with increased addition of HOAc. ${ }^{23-28}$ For complex 2, upon the addition of HOAc into the $\mathrm{CH}_{3} \mathrm{CN}$ solution, a new peak appeared at $-2.27 \mathrm{~V}$ versus $\mathrm{Ag} / \mathrm{AgNO}_{3}$. As with complex 1, this new reduction peak shows an enlargement with the addition of HOAc. According to these observations, it was hypothesized that complexes $\mathbf{1}$ and $\mathbf{2}$ can combine with protons and be activated to catalyze $\mathrm{H}_{2}$ production. By calculating the overpotential using the method described by Evans et al., ${ }^{29}$ the overpotentials of complexes 1 and 2 are found to be $0.91 \mathrm{~V}$ and $0.81 \mathrm{~V}$, respectively. Electrocatalysts with low overpotentials turn out to be more efficient and desirable, indicating that complex 2 has higher electrocatalytic activity.

Especially, to evaluate the electrocatalytic abilities for $\mathrm{H}_{2}$ production catalyzed by complexes 1 and 2 in $\mathrm{N}_{2}$ atmosphere, we used the ratio of catalytic current $\left(i_{\text {cat }}\right)$ to reductive peak current $\left(i_{\mathrm{p}}\right)$ in the absence of added acid as a marker to compare the electrocatalytic abilities of $\mathbf{1}$ and $\mathbf{2}$, where a higher value of $i_{\text {cat }} / i_{\mathrm{p}}$ indicates a higher catalytic activity. ${ }^{30}$ It can be seen from Table 4 that the $i_{\text {cat }} / i_{\mathrm{p}}$ values of $\mathbf{1}$ and 2 in $\mathrm{N}_{2}$ atmosphere indicate that complex 2 has a better electrocatalytic activity than 
Table 1 Crystal data and structure refinement for complexes 1 and 2

\begin{tabular}{|c|c|c|}
\hline Complex & 1 & 2 \\
\hline Empirical formula & $\mathrm{C}_{12} \mathrm{H}_{17} \mathrm{Fe}_{2} \mathrm{O}_{5} \mathrm{PS}_{2}$ & $\mathrm{C}_{12} \mathrm{H}_{17} \mathrm{Fe}_{2} \mathrm{O}_{8} \mathrm{PS}_{2}$ \\
\hline Formula weight & 448.04 & 496.05 \\
\hline Crystal system & Orthorhombic & Monoclinic \\
\hline Space group & Pbcn & $C 2 / c$ \\
\hline$a / \AA$ & $23.9678(4)$ & $11.163(2)$ \\
\hline$\alpha /^{\circ}$ & 90 & 90 \\
\hline$\beta /^{\circ}$ & 90 & $98.118(3)$ \\
\hline$\gamma / /^{\circ}$ & 90 & 90 \\
\hline Volume $/ \AA^{3}$ & $3550.25(10)$ & $3798.1(12)$ \\
\hline$Z$ & 8 & 8 \\
\hline$\rho_{\text {calc }} \mathrm{g} \mathrm{cm}^{-3}$ & 1.676 & 1.735 \\
\hline $2 \theta$ range for data collection & 3.398 to 57.398 & 3.06 to 25.02 \\
\hline Index ranges & $\begin{array}{l}-32 \leq h \leq 32 \\
-15 \leq k \leq 15 \\
-17 \leq l \leq 17\end{array}$ & $\begin{array}{l}-13 \leq h \leq 13 \\
-14 \leq k \leq 17 \\
-27 \leq l \leq 27\end{array}$ \\
\hline Reflections collected & 45269 & 15557 \\
\hline Independent reflections & $4586\left[R_{\mathrm{int}}=0.0205, R_{\text {sigma }}=0.0096\right]$ & $3335\left[R_{\mathrm{int}}=0.0708\right]$ \\
\hline Data/restraints/parameters & $4586 / 0 / 203$ & $3335 / 192 / 281$ \\
\hline Goodness-of-fit on $F^{2}$ & 1.034 & 1.078 \\
\hline Final $R$ indexes $[I \geqq 2 \sigma(I)]$ & $R_{1}=0.0157, \mathrm{w} R_{2}=0.0410$ & $R_{1}=0.0754, \mathrm{w} R_{2}=0.2036$ \\
\hline Final $R$ indexes [all data] & $R_{1}=0.0170, \mathrm{w} R_{2}=0.0415$ & $R_{1}=0.0768, \mathrm{w} R_{2}=0.2048$ \\
\hline Largest diff. peak/hole/e $\AA^{-3}$ & $0.35 /-0.20$ & $1.411 /-0.599$ \\
\hline
\end{tabular}

Table 2 Select bond lengths $(\AA \AA)$ for complexes 1 and 2

\begin{tabular}{lll}
\hline & 1 & 2 \\
\hline $\mathrm{Fe}(1)-\mathrm{Fe}(2)$ & $2.5235(2)$ & $2.4911(13)$ \\
$\mathrm{Fe}(1)-\mathrm{S}(1)$ & $2.2387(3)$ & $2.228(2)$ \\
$\mathrm{Fe}(1)-\mathrm{S}(2)$ & $2.2407(3)$ & $2.247(2)$ \\
$\mathrm{Fe}(2)-\mathrm{S}(1)$ & $2.2545(3)$ & $2.247(2)$ \\
$\mathrm{Fe}(2)-\mathrm{S}(2)$ & $2.2701(3)$ & $2.257(2)$ \\
$\mathrm{Fe}(1)-\mathrm{P}(1)$ & $2.2258(3)$ & $2.164(2)$
\end{tabular}

Table 3 Select bond angles $\left(^{\circ}\right)$ for complexes 1 and 2

\begin{tabular}{lll}
\hline & 1 & 2 \\
\hline $\mathrm{S}(1)-\mathrm{Fe}(1)-\mathrm{Fe}(2)$ & $56.129(8)$ & $56.55(6)$ \\
$\mathrm{S}(1)-\mathrm{Fe}(2)-\mathrm{Fe}(1)$ & $55.534(8)$ & $55.81(6)$ \\
$\mathrm{S}(2)-\mathrm{Fe}(1)-\mathrm{Fe}(2)$ & $56.537(8)$ & $56.62(5)$ \\
$\mathrm{S}(2)-\mathrm{Fe}(2)-\mathrm{Fe}(1)$ & $55.432(7)$ & $56.22(5)$ \\
$\mathrm{P}(1)-\mathrm{Fe}(1)-\mathrm{Fe}(2)$ & $106.465(9)$ & $154.20(7)$
\end{tabular}

complex 1, which is indicative of the considerable influence of phosphine ligands on the redox properties of iron cores in the ligand-substituted diiron dithiolate complexes. ${ }^{31}$

Inspired by the study by DuBois et al., ${ }^{32}$ we also tried to explore the catalytic hydrogen evolution in aqueous media. Cyclic voltammetry was carried out in the presence of water in $\mathrm{CH}_{3} \mathrm{CN}$. As shown in Fig. 7, following the addition of water to the solution, the reduction peak currents of both complexes 1 and 2 increase as the concentration of $\mathrm{H}_{2} \mathrm{O}$ increased, and no positive or negative shift is observed in the two reduction peaks. It indicated that complexes $\mathbf{1}$ and $\mathbf{2}$ displayed catalytic functions in water for $\mathrm{H}_{2}$ formation. Similarly, to evaluate the electrocatalytic abilities for $\mathrm{H}_{2}$ production of complexes 1 and $2, i_{\text {cat }} / i_{\mathrm{p}}$ are shown in Table 5. These results also indicate that complex 2 has better electrocatalytic activity than complex 1 . Further study of the electrocatalytic ability of complexes $\mathbf{1}$ and 2 was performed in a double compartment cell, wherein the bulk

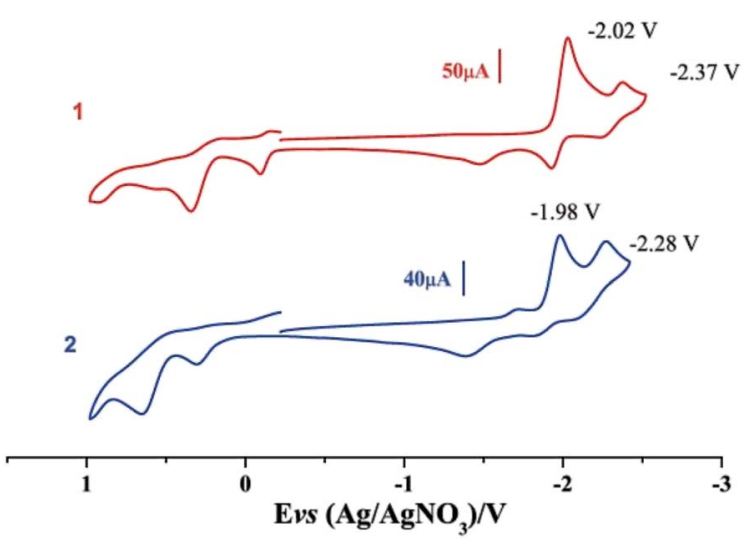

Fig. 3 Cyclic voltammograms of complexes 1 and 2 in $\mathrm{CH}_{3} \mathrm{CN}$ under $\mathrm{N}_{2}$ atmosphere (0.1 $\mathrm{Mn}-\mathrm{Bu}_{4} \mathrm{PF}_{6}, 200 \mathrm{mV} \mathrm{s}^{-1}$ scan rate). 


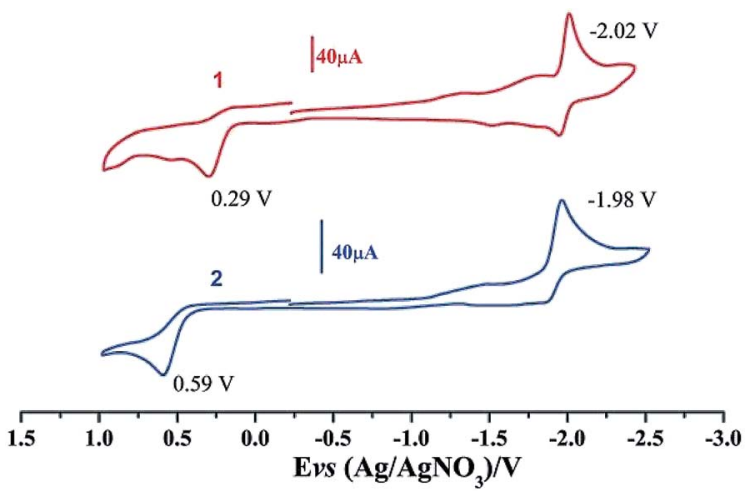

Fig. 4 Cyclic voltammograms of complexes 1 and 2 in $\mathrm{CH}_{3} \mathrm{CN}$ solution under $\mathrm{CO}$ atmosphere $\left(0.1 \mathrm{Mn}-\mathrm{Bu}_{4} \mathrm{PF}_{6}, 200 \mathrm{mV} \mathrm{s}{ }^{-1}\right.$ scan rate).

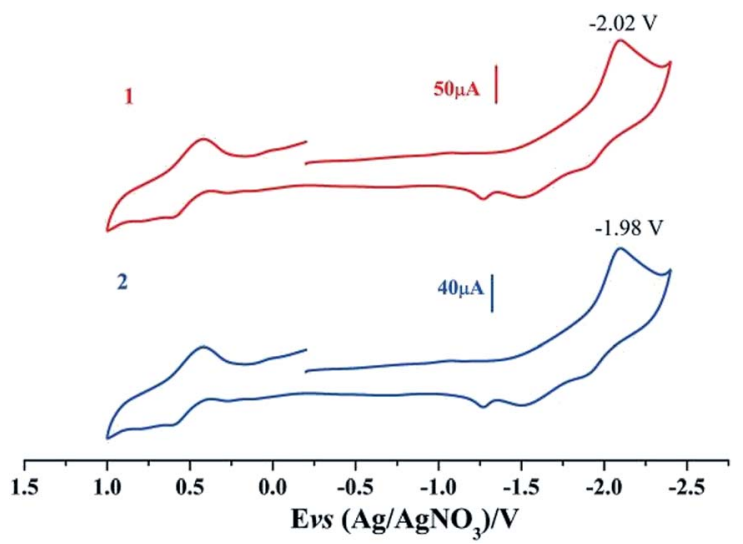

Fig. 5 Cyclic voltammograms of complexes 1 and 2 in $\mathrm{CH}_{2} \mathrm{Cl}_{2}$ solution under $\mathrm{N}_{2}$ atmosphere (0.1 $\mathrm{Mn}-\mathrm{Bu}_{4} \mathrm{PF}_{6}, 200 \mathrm{mV} \mathrm{s}{ }^{-1}$ scan rate).

electrolysis of complexes 1-2 (1 mM) with HOAc $(6 \mathrm{mM})$ was conducted at $-2.30 \mathrm{~V}$ for $10 \mathrm{~min}$. The maximum charge for $\mathbf{1}$ and 2 were $31.3 \mathrm{mC}$ and $56.3 \mathrm{mC}$, respectively.

\section{Experimental}

\section{General methods and materials}

Inert $\left(\mathrm{N}_{2}\right)$ atmosphere and Schlenk line techniques were used for the reactions related to the synthesis of model complexes. $\mu$ $\left(\mathrm{SCH}\left(\mathrm{CH}_{2} \mathrm{CH}_{3}\right) \mathrm{CH}_{2} \mathrm{~S}\right)-\mathrm{Fe}_{2}(\mathrm{CO})_{6}$ was prepared by the published process. $\mathrm{HOAc}, \mathrm{CH}_{3} \mathrm{CN}, n$-hexane, $\mathrm{CDCl}_{3}$ and $\mathrm{CH}_{2} \mathrm{Cl}_{2}$ were obtained from Guangfu Chemicals (China). These reagents were all deoxygenated and dewatered on each and every occasion before use. $\mathrm{Fe}(\mathrm{CO})_{5}$, trimethylphosphine, trimethyl phosphite, 1,2-butanedithiol, $\mathrm{AgNO}_{3}$, phosphate buffers, ferrocene, $n$ $\mathrm{Bu}_{4} \mathrm{NPF}_{6}$ and other reagents were bought from Sigma-Aldrich. NMR spectra were obtained on a Bruker AVANCE III $400 \mathrm{MHz}$ NMR spectrometer. Solution IR spectra were recorded on a Shimadzu FTIR-8400 spectrometer. Heraeus CHN-Rapid, fully automatic elemental analyzer with TCD detection, type: TMT CHN, BESTELL-NR 2215001, was used for elemental analysis. Using a Rigaku MM-007 diffractometer along with a Saturn 724CCD, the single-crystal X-ray diffraction data were gathered at $113.15 \mathrm{~K}$ with a confocal monochromator in $\mathrm{Mo}-\mathrm{K} \alpha$ radiation
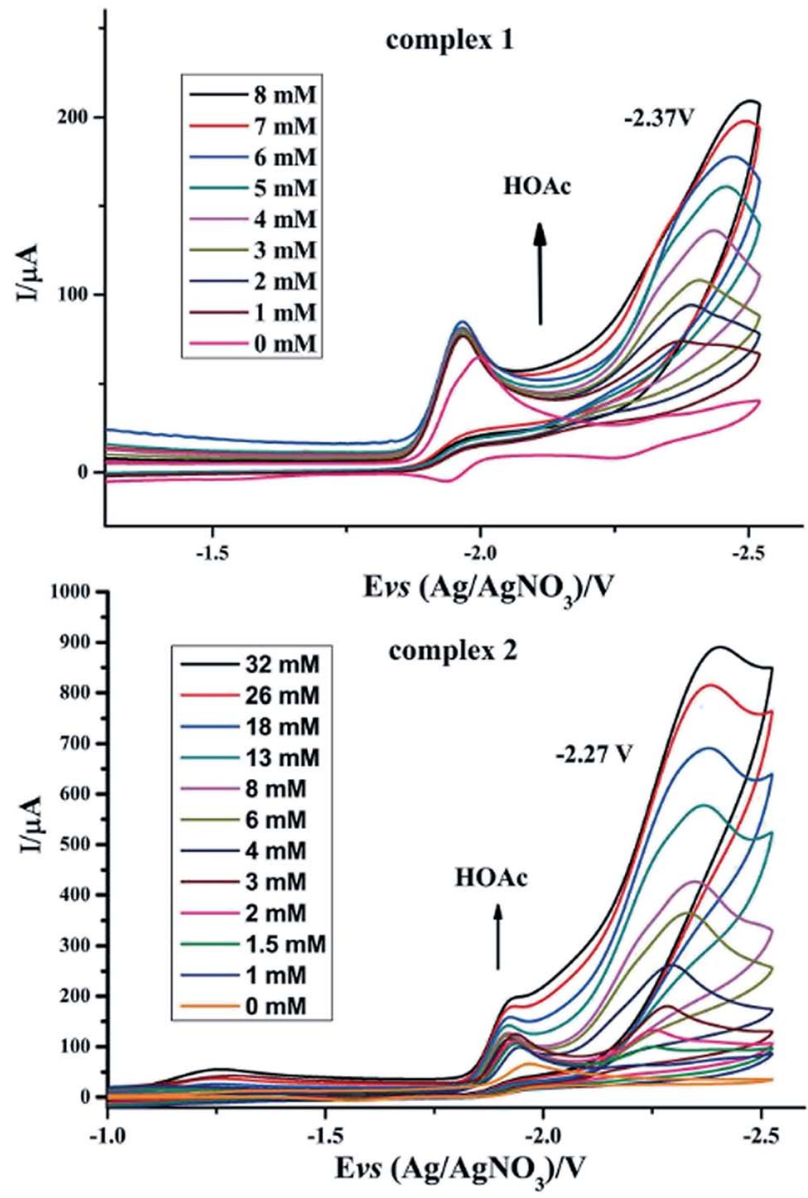

Fig. 6 Cyclic voltammograms of complexes 1 and $2(1 \mathrm{mM})$ in $\mathrm{CH}_{3} \mathrm{CN}$ solution with different amounts of $\mathrm{HOAc}\left(0.1 \mathrm{Mn} n-\mathrm{Bu}_{4} \mathrm{NPF}_{6}\right)$ under $\mathrm{N}_{2}$ at room temperature; scan rate, $0.2 \mathrm{~V} \mathrm{~s}^{-1}$.

Table 4 The relevant electrochemical and electrocatalytic data for 1 and 2 in $\mathrm{N}_{2}$ atmosphere

\begin{tabular}{llllll}
\hline Complex & Atmosphere & $E_{\mathrm{pc}}{ }^{a}(\mathrm{~V})$ & $i_{\mathrm{p}}(\mu \mathrm{A})$ & $i_{\text {cat }}{ }^{b}(\mu \mathrm{A})$ & $i_{\text {cat }} / i_{\mathrm{p}}$ \\
\hline 1 & $\mathrm{~N}_{2}$ & 2.02 & 64.17 & 208.25 & 3.24 \\
2 & $\mathrm{~N}_{2}$ & 1.98 & 67.14 & 428.51 & 6.21
\end{tabular}

${ }^{a}$ All data for 1 and $2(1 \mathrm{mM})$ are versus $\mathrm{Ag} / \mathrm{AgNO}_{3}$ in $0.1 \mathrm{M} n-\mathrm{Bu}_{4} \mathrm{NPF}_{6} /$ MeCN at a scan rate of $200 \mathrm{mV} \mathrm{s}^{-1} \cdot{ }^{b} i_{\text {cat }}$ is the catalytic current at the highest concentration of HOAc $(8 \mathrm{mM})$.

$(\lambda=0.71073 \AA)$. Data gathering, reduction, as well as absorption rectification were conducted on the CRYSTALCLEAR program. ${ }^{33}$ Structural issues were addressed by direct approaches in SHELXL-97 program 47 and also refined by SHELXL-97 on $F^{2}$. Electrochemical measurements in $\mathrm{CH}_{3} \mathrm{CN}$ solutions ( $c a .1 \mathrm{mmol}$ $\mathrm{L}^{-1}$ ) under $\mathrm{N}_{2}$ were carried out with a three-electrode CHI760B electrochemical workstation.

\section{Synthesis of $\mu$ - $\left(\mathrm{SCH}\left(\mathrm{CH}_{2} \mathrm{CH}_{3}\right) \mathrm{CH}_{2} \mathrm{~S}\right)-\mathrm{Fe}_{2}(\mathrm{CO})_{5} \mathrm{PMe}_{3}(1)$}

$\mu-\left(\mathrm{SCH}\left(\mathrm{CH}_{2} \mathrm{CH}_{3}\right) \mathrm{CH}_{2} \mathrm{~S}\right)-\mathrm{Fe}_{2}(\mathrm{CO})_{6}(0.21 \mathrm{mmol}, 82 \mathrm{mg})$ and $\mathrm{PMe}_{3}$ $(0.23 \mathrm{mmol}, 15.6 \mathrm{mg})$ were mixed in $n$-hexane solvent $(5 \mathrm{~mL})$ 

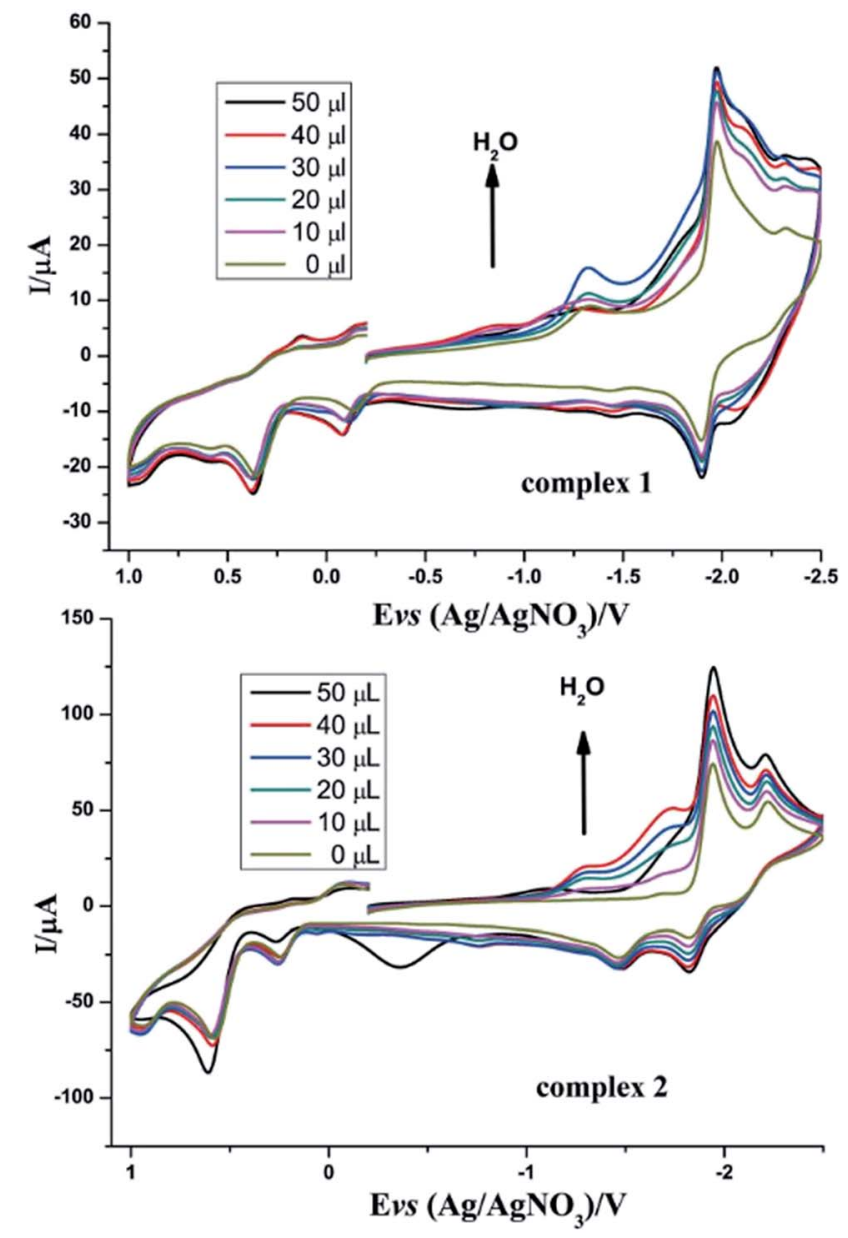

Fig. 7 Cyclic voltammograms of complexes 1 and $2(1 \mathrm{mM})$ detailing the effect of $\mathrm{H}_{2} \mathrm{O}$ on the catalytic proton reduction in $\mathrm{CH}_{3} \mathrm{CN}$ solution $\left(0.1 \mathrm{Mn}-\mathrm{Bu}_{4} \mathrm{NPF}_{6}\right)$ under $\mathrm{N}_{2}$ at room temperature; scan rate, $0.2 \mathrm{~V} \mathrm{~s}^{-1}$.

Table 5 The relevant electrochemical and electrocatalytic data for 1 and 2 in $\mathrm{N}_{2}$ atmosphere

\begin{tabular}{llllcl}
\hline Complex & Atmosphere & $E_{\mathrm{pc}}{ }^{a}(\mathrm{~V})$ & $i_{\mathrm{p}}(\mu \mathrm{A})$ & $i_{\text {cat }}{ }^{b}(\mu \mathrm{A})$ & $i_{\text {cat }} / i_{\mathrm{p}}$ \\
\hline 1 & $\mathrm{~N}_{2}$ & 2.02 & 38.62 & 52.38 & 1.35 \\
2 & $\mathrm{~N}_{2}$ & 1.98 & 73.16 & 125.86 & 1.72
\end{tabular}

${ }^{a}$ All data for 1 and $2(1 \mathrm{mM})$ are versus $\mathrm{Ag} / \mathrm{AgNO}_{3}$ in $0.1 \mathrm{M} n-\mathrm{Bu}_{4} \mathrm{NPF}_{6} /$ MeCN at a scan rate of $0.2 \mathrm{~V} \mathrm{~s}^{-1} \cdot{ }^{b} i_{\text {cat }}$ is the catalytic current at the highest concentration of $\mathrm{H}_{2} \mathrm{O}(50 \mu \mathrm{L})$.

under $\mathrm{N}_{2}$ atmosphere. The reaction solution was continuously stirred at ambient temperature under $\mathrm{N}_{2}$ for $24 \mathrm{~h}$. After the solvent was evaporated under vacuum, the crude residue was isolated by column chromatography using $n$-hexane as eluent. Yield (19.28 mg, 21\%). ${ }^{1} \mathrm{H}$ NMR $\left(\mathrm{CDCl}_{3}\right): \delta=0.90,1.05,1.28(\mathrm{~d}$, $\left.3 \mathrm{H}, \mathrm{CH}_{3}\right), \delta=1.51,1.52\left(\mathrm{~d}, 9 \mathrm{H}, \mathrm{CH}_{3}\right), \delta=1.69\left(\mathrm{~m}, 2 \mathrm{H}, \mathrm{CH}_{2}\right)$, and $\delta=2.46,2.63\left(\mathrm{~m}, 3 \mathrm{H},-\mathrm{CH}-\mathrm{CH}_{2}-\right) ;{ }^{13} \mathrm{C} \mathrm{NMR}\left(\mathrm{CDCl}_{3}\right): \delta_{\mathrm{CO} \text { at Fe1 }}=$ $211.63, \delta_{\mathrm{CO}}$ at $\mathrm{Fe} 2, \mathrm{Fe}-\mathrm{P}=210.34, \delta_{\text {dalkyl }}=14.04,30.22,42.03$, 55.75 , and $\delta_{\mathrm{P}\left(\mathrm{CH}_{3}\right)_{3}}=20.45,20.74 ;{ }^{31} \mathrm{P} \mathrm{NMR}\left(400 \mathrm{MHz}, \mathrm{CDCl}_{3}\right)$ : 22.82 (s). Elemental anal. calc. (\%) for $\mathrm{C}_{12} \mathrm{H}_{17} \mathrm{Fe}_{2} \mathrm{O}_{5} \mathrm{PS}_{2}$ : C, 32.17; $\mathrm{H}, 3.82$; found (\%): C, 32.10; H, 3.78.
Synthesis of $\mu$-( $\left.\mathrm{SCH}\left(\mathrm{CH}_{2} \mathrm{CH}_{3}\right) \mathrm{CH}_{2} \mathrm{~S}\right)-\mathrm{Fe}_{2}(\mathrm{CO})_{5} \mathrm{P}\left(\mathrm{CH}_{3} \mathrm{O}\right)_{3}$ (2)

$\mu-\left(\mathrm{SCH}\left(\mathrm{CH}_{2} \mathrm{CH}_{3}\right) \mathrm{CH}_{2} \mathrm{~S}\right)-\mathrm{Fe}_{2}(\mathrm{CO})_{6}(84 \mathrm{mg}, 0.21 \mathrm{mmol})$ was dissolved in dry THF $(5 \mathrm{~mL})$ under nitrogen, and then $\mathrm{Me}_{3} \mathrm{NO}$ (24 mg, $0.24 \mathrm{mmol}$ ) was added. After stirring at room temperature for $0.5 \mathrm{~h}, \mathrm{P}\left(\mathrm{CH}_{3} \mathrm{O}\right)_{3}(27 \mathrm{mg}, 0.21 \mathrm{mmol})$ was added and the mixture was continuously stirred for $6 \mathrm{~h}$ at room temperature. The solution was evaporated to dryness. The residue was subjected to preparative gel silica column chromatography using nhexane as the eluent. From the main red band, complex 2 was obtained as a red solid (65.12 mg, 62\%). ${ }^{1} \mathrm{H} \mathrm{NMR}\left(\mathrm{CDCl}_{3}\right): \delta=$ $0.91,1.06,1.30\left(\mathrm{~d}, 3 \mathrm{H}, \mathrm{CH}_{3}\right), \delta=1.49,1.53\left(\mathrm{~d}, 9 \mathrm{H}, \mathrm{CH}_{3}\right), \delta=1.66$ $\left(\mathrm{m}, 2 \mathrm{H}, \mathrm{CH}_{2}\right)$, and $\delta=2.47,2.67\left(\mathrm{~m}, 3 \mathrm{H},-\mathrm{CH}-\mathrm{CH}_{2}-\right) ;{ }^{13} \mathrm{C} \mathrm{NMR}$ $\left(\mathrm{CDCl}_{3}\right): \delta_{\mathrm{CO} \text { at Fe} 2}=209.83, \delta_{\mathrm{CO}}$ at Fe1, Fe-P $=207.53, \delta_{\text {dalkyl }}=$ 14.17, 29.43, 41.38, 51.90, and $d_{\mathrm{P}\left(\mathrm{CH}_{3}\right)_{3}}=20.45,20.74 ;{ }^{31} \mathrm{P} \mathrm{NMR}$ $\left(400 \mathrm{MHz}, \mathrm{CDCl}_{3}\right): 49.75$; Elemental anal. calc. for $\mathrm{C}_{12} \mathrm{H}_{17} \mathrm{Fe}_{2}-$ $\mathrm{O}_{8} \mathrm{PS}_{2}$ : C, 29.97; H, 3.45; found: C, 30.06; H, 3.43.

\section{Conclusions}

In conclusion, we successfully prepared the complexes $\mu$ $\left(\mathrm{SCH}\left(\mathrm{CH}_{2} \mathrm{CH}_{3}\right) \mathrm{CH}_{2} \mathrm{~S}\right)-\mathrm{Fe}_{2}(\mathrm{CO})_{5} \mathrm{PMe}_{3} \mathbf{1}$ and $\mu-\left(\mathrm{SCH}\left(\mathrm{CH}_{2} \mathrm{CH}_{3}\right)\right.$ $\left.\mathrm{CH}_{2} \mathrm{~S}\right)-\mathrm{Fe}_{2}(\mathrm{CO})_{5} \mathrm{P}\left(\mathrm{CH}_{3} \mathrm{O}\right)_{3}$ 2. The molecular structures of compounds 1 and $\mathbf{2}$ were well characterized by spectroscopic methods and X-ray crystallography. Electrochemical studies showed that the complexes $\mathbf{1}$ and 2, as novel electrocatalysts, have the ability to catalyze hydrogen production from HOAc or $\mathrm{H}_{2} \mathrm{O}$.

In the presence of $\mathrm{HOAc}$ in $\mathrm{CH}_{3} \mathrm{CN}$ solution, the hydrogen evolution overpotentials of complexes 1 and 2 were $0.91 \mathrm{~V}$ and $0.81 \mathrm{~V}$, respectively. Comparatively, complex 2 produced hydrogen at an overpotential of $0.1 \mathrm{~V}$, lower than that of complex 1. Further study of the electrocatalytic abilities of complexes 1 and 2 was performed in a double compartment cell; the bulk electrolysis of complexes 1 and $2(1 \mathrm{mM})$ with HOAc $(6 \mathrm{mM})$ was conducted at $-2.30 \mathrm{~V}$ for $10 \mathrm{~min}$. The maximum charge for 1 and 2 were $31.3 \mathrm{mC}$ and $56.3 \mathrm{mC}$, respectively. These results also indicate that complex 2 has better electrocatalytic activity than complex 1 . This possibly implies that the steric and electronic character of the [2Fe2S] model complexes with different substituted-ligands might be much closer to the hydrogen production capacity. These will be relevant to the natural metalloenzyme systems and crucial to their potential industrial application. The results derived from complexes with different ligand substitution enable us to develop more efficient bio-inspired catalytic systems based on the geologically-abundant metals.

\section{Conflicts of interest}

There are no conflicts of interest to declare.

\section{Acknowledgements}

We are grateful to the National Key R\&D Program of China (2017YFB0404701) for financial support. 


\section{Notes and references}

1 P. Hoffmann and B. Dorgan, Int. J. Hydrogen Energy, 2002, 3, 16.

2 R. Cammack, Nature, 1999, 397, 214-215.

3 S. Shima and R. K. Thauer, Chem. Rec., 2007, 7, 37-46.

4 C. Tard and C. J. Pickett, Chem. Rev., 2009, 109, 2245-2274.

5 T. R. Simmons, G. Berggren, M. Bacchi, M. Fontecave and

V. Artero, Coord. Chem. Rev., 2014, 127, 270-271.

6 T. Xu, D. Chen and X. Hu, Coord. Chem. Rev., 2015, 303, 3241.

7 Y. Nicolet, C. Piras, P. Legrand, C. E. Hatchikian and J. C. Fontecillacamps, Structure, 1997, 7, 13-23.

8 J. W. Peters, W. N. Lanzilotta, B. J. Lemon and L. C. Seefeldt, Science, 1998, 282, 1853-1858.

9 S. Ezzaher, J. F. Capon, F. Gloaguen, F. Y. Petillon, P. Schollhammer and J. Talarmin, Inorg. Chem., 2009, 48, 2-4.

10 S. Ghosh, A. Rahaman, K. B. Holt, E. Nordlander, M. G. Richmond, S. E. Kabir and G. Hogarth, Polyhedron, 2016, 116, 127-135.

11 M. Q. Hu, C. B. Ma, X. F. Zhang, F. Chen, C. N. Chen and Q. T. Liu, Chem. Lett., 2006, 35, 840-841.

12 J. F. Capon, S. E. Hassnaoui, F. Gloaguen, P. Schollhammer and J. Talarmin, Organometallics, 2005, 24, 2020-2022.

13 C. G. Li, Y. Zhu, X. X. Jiao and X. Q. Fu, Polyhedron, 2014, 67, 416-421.

14 P. H. Zhao, X. H. Li, Y. F. Liu and Y. Q. Liu, J. Coord. Chem., 2014, 67, 766-778.

15 X. F. Liu and X. W. Xiao, J. Organomet. Chem., 2011, 696, 2767-2771.

16 X. F. Liu and B. S. Yin, J. Coord. Chem., 2010, 63, 4061-4067.

17 M. Lian, J. He, X. Yu, C. Mu, X. Liu, Y. Li and Z. Jiang, J. Organomet. Chem., 2018, 870, 90-96.

18 S. Ghosh, S. Basak-Modi, M. G. Richmond, E. Nordlander and G. Hogarth, Inorg. Chim. Acta, 2018, 480, 47-53.

19 P. Zhao, Z. Ma, M. Hu, J. He, Y. Wang, X. Jing, H. Chen, Z. Wang and Y. Li, Organometallics, 2018, 37, 1280-1290.
20 X. Zhang, T. Y. Zhang, B. Li, G. H. Zhang, L. Hai, X. Y. Ma and W. B. Wu, RSC Adv., 2017, 7, 2934-2942.

21 P. Li, M. Wang, C. He, X. liu, K. Jin and L. Sun, Eur. J. Inorg. Chem., 2007, 23, 3718-3727.

22 S. Roy, J. A. Laureanti, T. L. Groy and A. K. Jones, Eur. J. Inorg. Chem., 2017, 23, 2942-2950.

23 S. Roy, T. L. Groy and A. K. Jones, Dalton Trans., 2013, 42, 3843-3853.

24 X. H. Zeng, Z. M. Li, Z. Y. Xiao, Y. W. Wang and X. M. Liu, Electrochem. Commun., 2010, 12, 342-345.

25 J. Windhager, M. Rudolph, S. Bräutigam, H. Görls and W. Weigand, Eur. J. Inorg. Chem., 2007, 18, 2748-2760.

26 G. A. N. Felton, C. A. Mebi, B. J. Petro, A. K. Vannucci, D. H. Evans, R. S. Glass and D. L. Lichtenberger, J. Organomet. Chem., 2009, 694, 2681-2699.

27 R. Mejia-Rodriguez, D. Chong, J. H. Reibenspies, M. P. Soriaga and M. Y. Darensbourg, J. Am. Chem. Soc., 2004, 126, 12004-12014.

28 D. Chong, I. P. Georgakaki, R. Mejia-Rodriguez, J. SanabriaChinchilla, M. P. Soriaga and M. Y. Darensbourg, Dalton Trans., 2003, 21, 4158-4163.

29 A. K. Vannucci, S. Wang, G. S. Nichol, D. L. Lichtenberger, D. H. Evans and R. S. Glass, Dalton Trans., 2010, 39, 30503056.

30 R. X. Li, X. F. Liu, T. Liu, Y. B. Yin, Y. Zhou, S. K. Mei and J. Yan, Electrochim. Acta, 2017, 237, 207-216.

31 P. Li, M. Wang, C. J. He, G. H. Li, X. Y. Liu, C. N. Chen, B. Åkermark and L. Sun, Eur. J. Inorg. Chem., 2005, 12, 2506-2513.

32 U. J. Kilgore, J. A. S. Roberts, D. H. Pool, A. M. Appel, M. P. Stewart, M. R. DuBois, G. William, W. Dougherty, R. Scott Kassel, M. Bullock and D. L. DuBois, J. Am. Chem. Soc., 2011, 133, 5861-5872.

33 (a) G. M. Sheldrick, SHELXS-97, University of Göttingen, Göttingen, Germany, 1997; (b) O. Dolomanov and H. Puschmann, Acta Crystallogr., 2007, 63, 74-75. 